\title{
CENTRALIZATION OF DECISION MAKING AUTHORITY IN INTER- ORGANIZATIONAL NETWORKS: EVIDENCE FROM THE AUSTRIAN AUTOMOTIVE INDUSTRY
}

\author{
*Tugba GURCAYLILAR-YENIDOGAN \\ **Josef WINDSPERGER \\ *Akdeniz University, Turkey \\ **University of Vienna, Austria
}

\begin{abstract}
The aim of this study is to examine the impact of property rights and transaction cost variables (i.e., intangible knowledge assets, relationship-specific investments and environmental uncertainty) on centralization of decision making authority in the automotive networks. The theoretical view is based on the property rights theory and transaction cost theory that offer a complementary perspective to the agency-theoretical explanation. The data were collected from a field survey in the Austrian automotive networks. The findings show that centralization of decision making authority in the automotive networks is related to the automaker's and supplier's intangible knowledge assets and relationship-specific investments as well as environmental uncertainty.
\end{abstract}

Keywords: Automotive networks; Residual decision rights; Intangible knowledge assets; Relationshipspecific investments; Environmental uncertainty

\section{INTRODUCTION}

This paper aims to examine the determinants of the decision making structure in the context of relationships between automakers and their component suppliers. Automakers use contracts to transfer ownership and decision rights of the outsourced function to the suppliers (Mikkola, 2003). However, according to the transaction cost theory, (Williamson, 1985) bounded rationality of contractual parties (Simon, 1957) renders them unable to write complete contracts under uncertain future conditions. Whereas the initial contract does not completely specify the division of residual surplus, the unspecified portion of the contract leads to contractual hazards in sharing of quasi-rents and incentive problems regarding investing in relationship-specific assets (Grossman and Hart, 1986; Kim and Mahoney, 2005). Property rights theory (Grossman and Hart, 1986; Hart and Moore, 1990; Hart 1995) offers a complementary perspective to the agency theory by explaining ownership structure of the firm in an incomplete contract setting. According to the recent extensions of property rights theory, the owner is the one who has the residual rights of control over assets with residual returns on investments (Milgrom and Roberts, 1995; Kim and Mahoney, 2005). In other words, residual rights transfer the decision making authority to the owner of the rent-generating knowledge-based assets (co-specialized or individual) that cannot be explicitly specified in contracts. Hence, hold-up problems over the ex post division of surplus (Joskow, 2005) and the costs of transferring tacit knowledge can be mitigated (Jensen and Meckling, 1992; Windsperger, 2004) by delegating more decision making authority to the party who has more knowledge-based assets that generate a high stream of residual income. In addition, the delegation of decision making authority also decreases the delays in the process of transferring knowledge under environmental uncertainty (Zabojnik, 2002; Colombo and Delmastro, 2004). Despite its adaptive advantages, however, high degree of decision making power provided by delegation raises the issues of control (Jensen and Meckling, 1992; Xue et al., 2011). Accordingly, there is a shift towards a more centralized structure of decision making at higher levels of uncertainty when the control benefits outweigh the benefits of adaptation. 
Although many theoretical studies investigate how to allocate decision rights (Grossman and Hart, 1986; Hart and Moore, 1990; Brynjolfsson, 1994; Aghion and Tirole, 1997; Dessein, 2002; Zabojnik, 2002, Haris and Raviv, 2005), relatively little empirical research examines the determinants of allocation of decision rights in different organizational settings (Arruñada et al., 2001; Vázquez, 2004; Colombo and Delmastro, 2004; Windsperger, 2004; Windsperger and Jell, 2005; Mumdžiev and Windsperger, 2011; Hippmann and Windsperger, 2012; Mumdžiev and Windsperger, 2013). Colombo and Delmastro (2004) analyzed the factors of complexity, firm size, ownership status, urgency of decisions and the use of advanced communication technologies that effect the delegation of authority in the Italian manufacturing plants. Vázquez (2004) pointed out the effects of transactional attributes as well as the importance of organizational structure properties (i.e., size, property, age and unionism) and tested the links between transactional/behavioral traits (frequency of transactions, asset specificity, opportunism and uncertainty) and the allocation of decision rights in the Spanish food and electronics industries. In addition to the transactional and structural determinants of allocation of decision rights, Windsperger (2004) contributed to the franchising literature by explaining the influence of intangible knowledge assets on the structure of decision rights based on the property rights theory. On the other hand, Arruñada et al. (2001) analyzed the allocation of decision rights and monetary incentives in contractual relationships between automakers and dealers. Thereby they focused on the design of formal decision making processes and explored the effects of network characteristics (including product quality, length of the relationship and size of the network) on the allocation of completion, monitoring and termination rights.

Complementary to the view of Arruñada et al. (2001), this study focuses on property rights and transaction cost variables (intangible knowledge assets, relationship-specific investments and environmental uncertainty) that influence the degree of centralization of decision making authority in the automotive networks. In this study, the authors argue that the suppliers' sources of knowledgebased power (i.e., intangible knowledge assets) and the relationship-specific investments have negative effects on centralization of decision making authority whereas the impact of environmental uncertainty differs according to the adaptation or control requirements. The results obtained from the Austrian automotive networks support the theoretical predictions of the study. The findings show that more decision making authority is delegated to the component suppliers who have more intangible knowledge assets. Similarly, the empirical results provide evidence that suppliers' decision making authority increases with their investment in relationship-specific assets. In addition to the positive impact of environmental uncertainty on centralization of decision making due to control requirements, the moderating effect of environmental uncertainty on the relationship between intangible knowledge assets and centralization of decision making authority is supported by the data.

This study contributes to the literature in three important ways. First, this study integrates the multiple effects of rent-generating knowledge-based sources into the model that explores the determinants of the decision making structure: the effects of individual contributions in value-creating supply chain activities (i.e., design \& engineering, procurement, inbound logistics and production) and the effect of co-specific investments (Koss and Eaton, 1997) in product development. Second, this study discusses the conflicting effects of environmental uncertainty on centralization of decision making authority. Finally, this study contributes to the literature by providing evidence for the moderating effect of environmental uncertainty on the relationship between suppliers' intangible knowledge assets and centralization of decision making authority.

The paper proceeds in the following way. First, the hypotheses concerning the impact of knowledgebased assets and environmental uncertainty on centralization of decision making authority are developed and the moderating effect of environmental uncertainty on the relationships between intangible knowledge assets and centralization of decision making authority is discussed. Second, the data collection method and analytical procedures are explained in detail. Next, the hypotheses are tested with ordinal regression analyses. Finally, the research findings are presented and their implications are discussed. 


\title{
LITERATURE REVIEW AND HYPOTHESES
}

\author{
Intangible Knowledge Assets and Centralization
}

Based on the property rights view, the assignment of residual decision rights depends on the distribution of intangible assets that influence the residual income stream of the team production in network relationships (Windsperger, 2004). The portfolio of intangible assets consists of knowledge assets (i.e., know-how and reputation) as well as intellectual property assets (i.e., trademarks, patents, copyrights and registered designs) (Hall, 1992). Whereas intellectual property rights may be contractible, knowledge assets with a low degree of contractibility are the main issue for the allocation of residual decision rights (Hart and Moore, 1990; Brynjolfsson, 1994). The limited information storage and processing capacity of the economic agents makes it difficult to acquire and absorb knowledge. In this case, delays in making decisions give rise to the costs of transferring knowledge (Jensen and Meckling, 1992). When the cost of transferring knowledge is higher than the cost of transferring decision rights, more decision making authority is delegated to the holders of knowledge. Hence, (de)centralization of decision making authority increases the power of knowledge holders with their influence on the decisions regarding particular activity/functional areas (Young and Tavares, 2004). Consequently, in order to increase the returns from task specialization (Colombo and Delmastro, 2004) a higher portion of residual rights of control should be allocated to the suppliers, as automakers rely on suppliers' expertise in the development of new components and integrated systems customized to their specific requirements.

$\mathrm{H}_{1}$ : A higher centralization (decentralization) of decision making authority is associated with more intangible knowledge assets of the automakers (suppliers).

\section{Relationship-Specific Investments and Centralization}

In addition to the influence of intangible knowledge assets on the structure of decision rights, transaction cost economics and property rights reasoning enable to explain how the economic rent stream from the intangible asset portfolio should be shared between network partners (Westgren, 2000). In the automotive networks, supplier involvement in product development requires high investments in relationship-specific assets that generate ex post quasi-rents at stake (Masten, 1984). The investing parties (usually suppliers) face the hazards of ex post opportunism when the division of surplus is the subject of renegotiation (Segal and Whinston, 2000; Whinston, 2003; Martinez-Noya et al., 2012). Accordingly, the hold-up problems over the ex post division of surplus induce the parties to underinvest in specific assets. However, the allocation of rights to residual returns eliminates the bargaining problem over the appropriable ex post quasi-rents (Joskow, 2005). Hence network partners can maximize joint residual surplus by assigning residual income rights. On the other hand, the supplier's residual rights of control over specific and non-contractible knowledge assets effects the ex ante investment incentives by mitigating appropriability hazards arising from inadequate use of the knowledge transferred. In addition, the bonding effect of the supplier's relationship-specific investments reduces the monitoring costs of automakers when the quasi-rent stream generated by cospecific investments exceeds the potential gains from ex post opportunism (Klein et al., 1978; Rokkan et al., 2003; Hendrikse and Windsperger, 2011; Mumdžiev and Windsperger, 2013).

$\mathrm{H}_{2}$ : A higher centralization of decision making authority is associated with a lower level of relationship-specific investments.

\section{Environmental Uncertainty and Centralization: Adaptation vs. Control Effects}

High environmental uncertainty creates adaptation problems and increases the need for mutual adjustment between the network partners (March and Simon, 1958; Thompson, 1967; Williamson, 1975; Gulati et al., 2005). In order to respond to changing technologies and environment, automakers need to be able to adjust and upgrade their production technologies through co-development of their competencies together with suppliers (Fredericks, 2005; Joshi and Stump, 1999; Wang and Wei, 2007). According to Zabojnik (2002), delegation of decision making authority creates informationprocessing benefits through the flow of new information between network partners and hence 
facilitates sequential adaptations under high environmental uncertainty. Coordinated adaptation reduces leaks and delays in transmitting knowledge by encouraging the partners to perform concurrently (Zabojnik, 2002; Colombo and Delmastro, 2004). Therefore, it is assumed that decentralized decision making structures are more effective in a dynamic business environment to quickly respond to changes (Burns and Stalker, 1961; Aoki, 1986; Fan et al., 2003; Vázquez, 2004; Davis et al., 2009; Hippmann and Windsperger, 2012). Accordingly, the higher the environmental uncertainty, the more residual decision rights are assigned to component suppliers in order to utilize the benefits of adaptation and responsiveness provided by more decentralized structure of decision making.

$\mathrm{H}_{3 \mathrm{a}}$ : A higher decentralization of decision making authority is associated with higher environmental uncertainty.

On the other hand, decentralization of decision making authority also gives rise to problems of control. There is a trade-off between control and adaptation effects of delegation. The allocation of a higher portion of residual decision rights to the suppliers means a loss of control for automakers. According to the agency theory, the interest of the parties may not always align with the achievement of cooperative behavior (Milgrom and Roberts, 1992; Jensen and Meckling, 1992). In this case, the use of authority in a way that damages cooperative orientation to achieve common goals causes residual loss. Therefore, higher requirement of automakers to monitor the decisions over upstream value chain activities increases the costs of control. If the costs of control exceed the benefits of information processing under high uncertainty, automakers tend to centralize the structure of decision making to mitigate incentive conflicts (Xue et al., 2011). In addition, centralization of decision making authority facilitates the coordination of resources among different sourcing units. For example, global sourcing in the automotive industry is characterized by intense interdependencies among the operations. In this case, a more centralized structure of decision making provides flexibility to the automakers against changing environmental conditions. Thus automakers can decrease the external risks with a shift of sourcing towards the other suppliers as opportunities arise. Consequently, the higher the environmental uncertainty, the more residual decision rights are assigned to the automakers in order to reduce the residual loss arising from internal and external risks.

$\mathrm{H}_{3 \mathrm{~b}}$ : A higher centralization of decision making authority is associated with higher environmental uncertainty.

\section{Suppliers' Intangible Knowledge, Environmental Uncertainty and Centralization: The Moderating Effect of Environmental Uncertainty}

This study assumes that the influence of environmental uncertainty on the relationship between suppliers' intangible knowledge and centralization of decision making authority depends on two conflicting requirements: adaptation requirements vs. control requirements (Xue et al., 2011). Based on the need for adaptation and responsiveness, environmental uncertainty increases the negative effects on the relationship between supplier's intangible knowledge assets and centralization of decision making authority. In other words, under highly intangible knowledge assets of the supplier, the supplier's decision making authority increases with environmental uncertainty.

$\mathrm{H}_{4 \mathrm{a}}$ : Environmental uncertainty strengthens the negative impact of suppliers' intangible knowledge assets on centralization of decision making authority.

On the other hand, environmental uncertainty decreases the negative effects on the relationship between suppliers' intangible knowledge and centralization of decision making authority based on the need for control. The benefits of control and coordination outweigh the benefits of adaptation when environmental uncertainty increases to a higher level. Therefore, in the special case of a positive residual loss, there is a tendency towards a more centralized structure of decision making under a higher level of environmental uncertainty even if suppliers have more intangible knowledge.

$\mathrm{H}_{4 \mathrm{~b}}$ : Environmental uncertainty weakens the negative impact of suppliers' intangible knowledge assets on centralization of decision making authority. 


\section{Environmental Uncertainty, Relationship-Specific Investments and Centralization: The Moderating Effect of Relationship-Specific Investments}

The bonding effect of relationship-specific investments reduces the control costs of delegation under high environmental uncertainty by decreasing the relational risk arising from a more decentralized decision making structure (Klein et al., 1978; Mumdžiev and Windsperger, 2013). Hence, under high supplier's relationship-specific investments, decentralization of decision making authority facilitates mutually cooperative orientation in adjusting to changing environmental situations. Consistent with this argument, this study considers that relationship-specific investments may have moderating effects on the relationship between environmental uncertainty and centralization of decision making authority.

$\mathrm{H}_{5 \mathrm{a}}$ : Relationship-specific investments strengthen the negative impact of environmental uncertainty on centralization of decision making authority when the coordinated adaptation requirement increases.

$\mathrm{H}_{5 \mathrm{~b}}$ : Relationship-specific investments weaken the positive impact of environmental uncertainty on centralization of decision making authority when the control requirement decreases.

\section{METHODOLOGY \\ Sample and Data Collection}

The aim of this research is to analyze the impact of intangible knowledge assets and suppliers' relationship-specific investments as well as environmental uncertainty on centralization of decision making authority in the automotive networks. To test the hypotheses, a questionnaire-based survey was conducted in the year 2010. The empirical data of this study were collected from the supplier firms operating in the Austrian automotive industry. To determine the number of supplier firms in the population, the authors utilized the statistics of Austrian Automotive Association (AAA), Automotive Cluster of Vienna Region (ACVR), Automotive Cluster of Upper Austria and Automotive Cluster of Styria with the ranking list of top 100 global suppliers at automotivenews.com. After the cross check of the lists, it was concluded that the total of 275 component suppliers are operating in the Austrian automotive industry. In the data collection process, the total of 275 executives of the Austrian component suppliers were contacted via telephone and informed about the research. 193 firms accepted to participate in the research. Then the questionnaire was sent out electronically to the executives of suppliers who accepted to fill out the questionnaire; 83 valid responses were obtained. The data from the Austrian networks were analyzed with the SPSS (version 18) and the hypotheses were tested by applying ordinal regression analyses.

\section{Measurement}

Decision rights. In this study, decision rights relate to the structure of real authority (Aghion and Tirole, 1997; Hippmann and Windsperger, 2012) in the automotive networks. Following Heide and John (1992), this construct was measured with nine items to capture the extent to which residual decision rights are made by the automakers and the suppliers. According to the measurement of residual decision rights, component suppliers were asked to indicate who takes the decisions regarding the following value chain activities (Meyr et al., 2005; Talbot, 2007): design \& engineering, procurement, inbound logistics and production. These indicators were assessed on a 7-point Likert scale ranging from decisions solely taken by the supplier $(=1)$ and decisions solely taken by the automaker (=7). The value of Cronbach's alpha is 0.68 which is compatible with the recommended threshold level of 0.60 (Hair et al., 1998). By splitting the decision variable into three groups at its median, a decision index was constructed. The higher the index, the more residual decision rights are assigned to the automakers, and hence the higher is the degree of centralization.

Intangible knowledge. Intangible knowledge refers to the knowledge contribution of automakers and suppliers regarding the value-creating activities in the upstream supply chain. In the questionnaire, the supplier firms were asked to rate on a 7-point Likert scale to evaluate separately their own and the automakers' knowledge contribution to the supply chain activities. The scale includes six items regarding the value chain activities of design \& engineering, and production. Cronbach's alpha for the suppliers' intangible knowledge is 0.84 and for the automakers' intangible knowledge is 0.90 .

Relationship-specific investments. Relationship-specific investments concern the degree to which assets are dedicated to a particular relationship (Williamson, 1985). In this study, consistent with the 
studies of Asanuma (1989) and Dyer and Singh (1998), the items of the scale for the suppliers' relationship-specific investments are: (1) we are substantially involved in product development, (2) we spend much time in developing the specifications, (3) we spend much time and efforts in developing manufacturing and designing processes, (4) manufacturing of this product has created a specific expertise dedicated to our relationship. These four indicators were assessed on a 7-point Likert scale ranging from $1=$ strongly disagree to $7=$ strongly agree. The value of Cronbach's alpha is 0.84 .

Environmental uncertainty. This study focuses on environmental uncertainty associated with the dynamism of task environment (Lawrence and Lorsch, 1967, Thomson, 1967; Duncan, 1972; Williamson, 1975) as the strongest determinant of uncertainty in technology-intensive industries (Duncan, 1972; Bourgeois, 1980; Joshi and Campbell, 2003; Fredericks, 2005). Accordingly, the authors built on Bensaou and Venkatraman's construct of environmental dynamism as the rate of change in product arising from technological innovations (Bensaou and Venkatraman, 1995; Karimi et al., 2004). Environmental uncertainty associated with dynamism of task environment was measured with three items that belong to product's technical complexity, maturity of the underlying technology and the engineering content, as Bensaou and Venkatraman (1995) suggest. These indicators were assessed using 1-7 semantic differential scales for a component ranging from: (1) technically simple to technically complex, (2) based on mature technology to new technology, (3) low engineering effort and expertise to high engineering effort and expertise. Cronbach's alpha is 0.86 .

Control variables. One control variable labeled as supplier dependence, which might influence centralization of decision making in the network, was incorporated in the model. In order to measure supplier dependence, the supplier was asked to indicate the share of the automaker in its annual turnover.

\section{RESULTS}

\section{Descriptive Statistics}

Table 1 presents the descriptive statistics and Pearson correlation coefficients for all variables. As expected, centralization of decision making authority was negatively correlated with knowledge-based resources of suppliers, and relationship-specific investments, and positively correlated with automakers' intangible knowledge assets. Unexpectedly, there was no statistically significant relationship between centralization of decision making authority and environmental uncertainty; however its sign was positive. Similarly, centralization of decision making authority was positively but not significantly correlated with supplier dependence. Although significant correlation exists among some variables, none of the correlation coefficients is large enough $(>.80)$ to cause concern about severe multicollinearity (Hair et al., 1998). In addition, descriptive statistics basically show that there is a tendency towards a more decentralized structure of decision making in the Austrian automotive networks.

Table 1. Descriptive statistics and correlation coefficients

\begin{tabular}{|c|c|c|c|c|c|c|c|c|}
\hline \multirow[t]{2}{*}{ Variables } & \multirow[t]{2}{*}{ Mean } & \multirow[t]{2}{*}{ S.D. } & \multicolumn{6}{|c|}{ Correlations } \\
\hline & & & $\overline{1}$ & 2 & 3 & 4 & 5 & 6 \\
\hline 1. Decision rights & 2.83 & 0.94 & 1.000 & & & & & \\
\hline 2. Relationship-specific investments & 4.55 & 1.52 & $-0.282 *$ & 1.000 & & & & \\
\hline 3. Environmental uncertainty & 4.59 & 1.26 & 0.045 & $0.449 * *$ & 1.000 & & & \\
\hline 4. Suppliers' intangible knowledge & 6.03 & 1.10 & $-0.417 * *$ & $0.229 *$ & 0.067 & 1.000 & & \\
\hline 5. Automakers' intangible knowledge & 4.14 & 1.64 & $0.271 *$ & 0.081 & 0.187 & 0.018 & 1.000 & \\
\hline 6. Supplier dependence & 2.21 & 1.05 & 0.109 & $0.240 *$ & $0.330 * *$ & 0.082 & 0.026 & 1.000 \\
\hline
\end{tabular}

*p $<0.05, * * \mathrm{p}<0.01$ (two-tailed tests)

\section{Regression Analysis}

The regression analyses were conducted with the index of decision rights as an ordinal dependent variable to test the hypotheses. Table 2 reports the results of the regression models. The significant chi-square statistic for each model $(\mathrm{p}<0.01)$ indicates that the final model gives a significant improvement over the baseline model. According to Pearson and Deviance statistic ( $p>0.05)$, each 
model fits the data well. The explanatory power of the dependent variable (see the difference between the values of Nagelkerke $\mathrm{R}^{2}$ ) increased from 0.450 to 0.489 by including the interaction effect between environmental uncertainty and suppliers' intangible knowledge in the model.

\section{Table 2. Ordinal regression results}

\begin{tabular}{|c|c|c|c|c|c|}
\hline \multirow{2}{*}{ Independent variables } & \multicolumn{5}{|c|}{ Coefficients } \\
\hline & Model 1 & Model 2 & Model 3 & Model 4 & Model 5 \\
\hline \multirow[t]{2}{*}{ Threshold constants } & $-5.873 * * *(1.758)$ & $-1.157^{* * *}(0.303)$ & $-1.258 * * *(0.324)$ & $-1.154^{* * *}(0.330)$ & $-1.373 * * *(0.365)$ \\
\hline & $+3.889 * *(1.679)$ & $+0.892 * * *(0.294)$ & $+1.039 * * *(0.315)$ & $+1.186^{* * *}(0.327)$ & $+0.950 * * *(0.339)$ \\
\hline Automakers' intangible knowledge & $+0.329 * * \quad(0.156)$ & $+0.527 * *(0.242)$ & $+0.587^{* *} \quad(0.255)$ & $+0.590^{* *}(0.268)$ & $+0.586 * * \quad(0.255)$ \\
\hline Suppliers' intangible knowledge & $-1.047 * * *(0.274)$ & $-1.032 * * *(0.296)$ & $-1.268^{* * *}(0.322)$ & $-1.269^{* * *}(0.337)$ & $-1.285^{* * *}(0.332)$ \\
\hline Relationship-specific investments & & $-0.444^{*} \quad(0.250)$ & $-0.780^{* * *}(0.299)$ & $-0.798^{* * *}(0.309)$ & $-0.788^{* * *}(0.306)$ \\
\hline Environmental uncertainty & & & $+0.715^{* *}(0.309)$ & $+0.781 * *(0.320)$ & $+0.673^{* *}(0.318)$ \\
\hline Suppliers' intangible knowledge*Environmental uncertainty & & & & $+0.655^{* *} \quad(0.333)$ & \\
\hline Environmental uncertainty*Relationship-specific investments & & & & & -0.199 \\
\hline Supplier dependence & $+0.586 * * \quad(0.253)$ & $+0.685^{* * *}(0.265)$ & $+0.588^{* *}(0.280)$ & $+0.570^{* *} \quad(0.283)$ & $+0.546^{*} \quad(0.284)$ \\
\hline \multicolumn{6}{|l|}{ Model statistics } \\
\hline Model chi-square & $25.517 * * *$ & $28.594 * * *$ & $36.745^{* * *}$ & $41.042 * * *$ & $37.344^{* * * *}$ \\
\hline -2 Log likelihood & 133.133 & 131.442 & 121.121 & 116.824 & 120.528 \\
\hline Nagelkerke $\mathrm{R}^{2}$ & 0.332 & 0.365 & 0.450 & 0.489 & 0.456 \\
\hline
\end{tabular}

Values in parentheses are standard errors.

${ }^{*} \mathrm{p}<0.1, * * \mathrm{p}<0.05, * * * \mathrm{p}<0.01$

Consistent with the predictions of $\mathrm{H}_{1}$ and $\mathrm{H}_{2}$, the results indicate that centralization of decision making authority decreases with increasing supplier's intangible knowledge and relationship-specific investments. In addition, automaker's intangible knowledge positively impacts its real authority and hence causes a more centralized structure of decision making. On the other hand, the relationship between environmental uncertainty and centralization of decision making authority is positive and significant, in support of $\mathrm{H}_{3 \mathrm{~b}}$, due to the automaker's higher control requirements under high environmental uncertainty. Regarding $\mathrm{H}_{4 \mathrm{~b}}$, the results show that environmental uncertainty significantly moderates the effect of suppliers' intangible knowledge on centralization of decision making authority (see Figure 1 for graphical display of the interaction effects). However, the data provides insufficient evidence for $\mathrm{H}_{5 \mathrm{~b}}$, that the positive impact of environmental uncertainty on centralization of decision making authority is lower under a higher level of relationship-specific investments (see Figure 2).

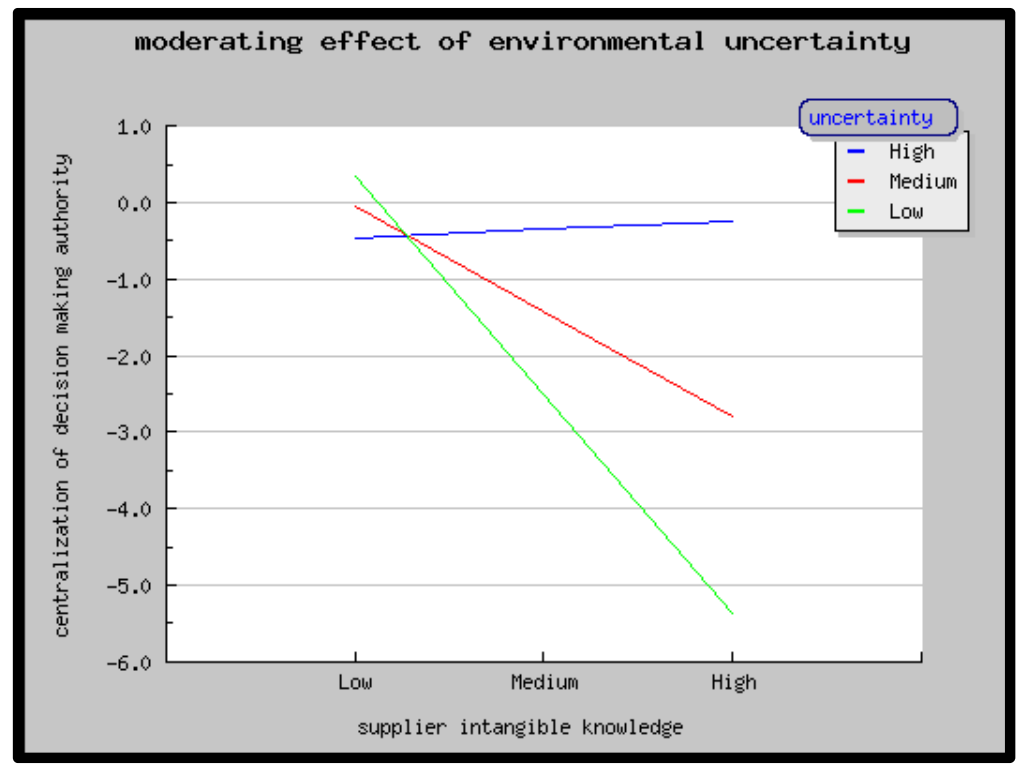

Figure 1. Moderating effect of environmental uncertainty on the relationship between suppliers' intangible knowledge and centralization of decision making authority (created by utilizing from the ModGraph programme of Jose, 2008) 


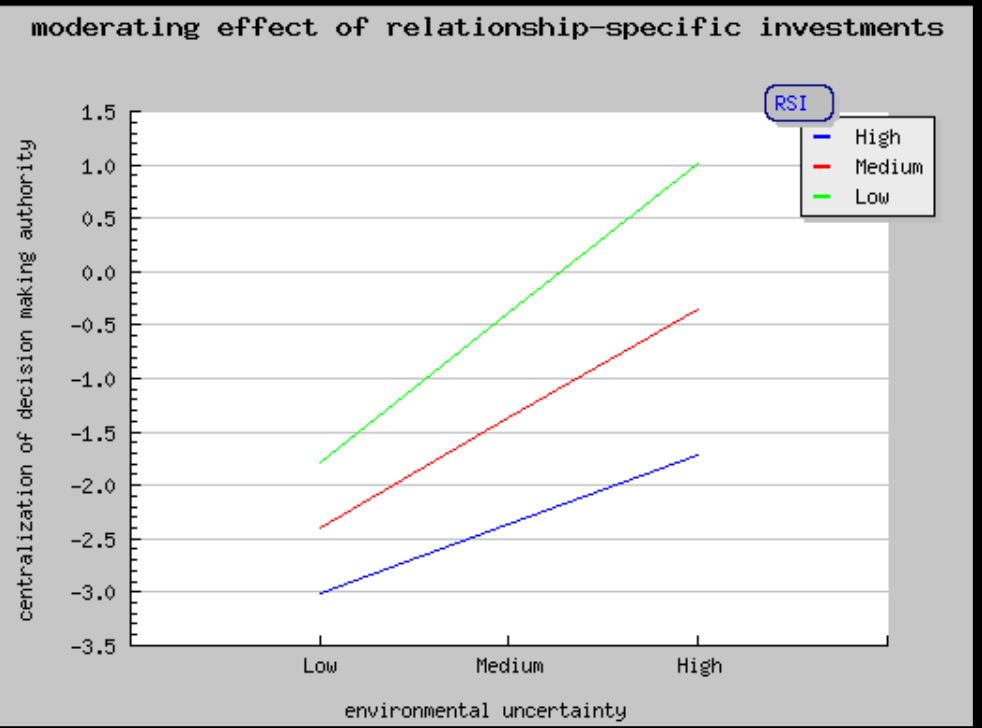

Figure 2. Moderating effect of relationship-specific investments on the relationship between environmental uncertainty and centralization of decision making authority (created by utilizing from the ModGraph programme of Jose, 2008)

\section{CONCLUSION}

The aim of this study is to examine the impact of property rights and transaction cost variables (i.e., the sources of knowledge-based power, relationship-specific investments and environmental uncertainty) on centralization of decision making authority in the automotive networks. The results from the Austrian automotive networks indicate that the suppliers' decision making power increases with their intangible knowledge assets over supply chain activities and their relationship-specific investments. Simultaneously, the automakers' control over decision making in the network increases with their intangible knowledge assets and environmental uncertainty. Moreover the results of the study show that the suppliers' contribution to the intangible knowledge assets in the supply chain leads to more decentralization of decision making, in particular when the environmental uncertainty is relatively low. However, this effect shifts towards more centralization of decision making in the automotive networks, due to high coordination and control costs, when environmental uncertainty strongly increases. Overall, this study contributes to the literature by developing a new view on allocation of real authority in supplier networks that integrates property rights and transaction cost explanations.

This study also has some managerial implications. The results indicate that the distribution of decision making power in the automotive networks depends on the knowledge contribution of automakers and suppliers, the relationship-specific investments and the environmental uncertainty. Accordingly, this study provides some recommendations for designing a more decentralized decision making structure in the automotive network. Although suppliers can have more decision making authority with their individual-level intangible knowledge assets, this effect shifts towards a more centralized decision making structure under a higher level of environmental uncertainty, in particular due to the automakers' increasing need to mitigate incentive conflicts and facilitate coordination of resources. Parallel production networks, which focus on the common use of product design and the integration of suppliers' knowledge stocks (i.e., design and process FMEA, process control plan, flow chart), result in a more centralized decision making structure in the automotive industry, even if suppliers have more intangible knowledge. However, relationship-specific investments mitigate opportunism risks and reduce the automakers' control requirement under high environmental uncertainty. In this case, the bonding effect of relationship-specific investments gives rise to a more decentralized structure of decision making authority in the automotive networks. 
The study has some limitations that create opportunities for future research. First, the research design of the study uses a single source of respondents. Future studies are needed to explore the relationships between the variables using multiple sources of respondents from both automakers and suppliers in the automotive supply chain in order to reduce the possibility of common methods bias. Second, future studies have to investigate the determinants of the decision making structure by collecting data from different inter-organizational relationships in order to increase the generalizability of the results. Third, the measures for decision rights and intangible knowledge assets need to be improved in such a way that enables to investigate the determinants of the allocation of disaggregated decision rights regarding the different value chain activities in the automotive networks. 


\section{REFERENCES}

Aghion, P. and Tirole, J. (1997). Formal and real authority in organizations. Journal of Political Economy, 105(1), pp.1-29.

Aoki, M. (1986). Horizontal vs. vertical information structure of the firm. American Economic Review, 76, pp.971-83.

Arruñada, B., Garicano, L. and Vázquez, L. (2001). Contractual allocation of decision rights and incentives: the case of automobile distribution. Journal of Law, Economics, and Organization, 17(1), pp.257-284.

Asanuma, B. (1989). Manufacturer-supplier relationships in Japan and the concept of relation-specific skill. Journal of the Japanese and International Economies, 3(1), pp.1-30.

Bensaou, M. and Venkatraman, N. (1995). Configurations of inter-organizational relationships: a comparison between U.S. and Japanese. Management Science, 41(9), pp.1471-1492.

Bourgeois, L.J. (1980). Strategy and environment: a conceptual integration. Academy of Management Review, 5(1), pp.25-39.

Brynjolfsson, E. (1994). Information assets, technology, and organization. Management Science, 40(12), pp.1645-1662.

Burns, T. and Stalker, G.M. (1961). The management of innovation, London: Tavistock.

Colombo, M. and Delmasto, M. (2004). Delegation of authority in business organizations: an empirical test. The Journal of Industrial Economics, 52, pp.53-80.

Davis, J.P., Eisenhardt, K.M. and Bingham, C.B. (2009). Optimal structure, market dynamism, and the strategy of simple rules. Administrative Science Quarterly, 54, pp.413-452.

Dessein, W. (2002). Authority and communication in organizations. Review of Economic Studies, 69(4), pp.811-838.

Duncan, R.B. (1972). Characteristics of organizational environments and perceived environmental uncertainty. Administrative Science Quarterly, 17(3), pp.313-327.

Dyer, J.H. and Singh, H. (1998). The relational view: cooperative strategy and sources of interorganizational competitive advantage. Academy of Management Review, 23(4), pp.600-679.

Fan, M, Stallaert, J. and Whinston, A.B. (2003). Decentralized mechanism design for supply chain organizations using an auction market. Information Systems Research, 14(1), pp.1-22.

Fredericks, E. (2005). Cross-functional involvement in new product development: a resource dependency and human capital perspective. Qualitative Market Research: An International Journal, 8(3), pp.327-341.

Grossman, S.J. and Hart, O.D. (1986). The cost and benefits of ownership: a theory of vertical and lateral integration. Journal of Political Economy, 94(4), pp.691-719.

Gulati, R., Lawrence, P.R. and Puranam, P. (2005). Adaptation vertical relationships: beyond incentive conflict. Strategic Management Journal, 26(5), pp.415-440.

Hair, J.F., Anderson, R.E., Tatham, R.L. and Black, W.C. (1998). Multivariate data analysis. Upper Saddle River, NJ: Pearson Education.

Hall, R. (1992). The strategic analysis of intangible resources. Strategic Management Journal, 13(2), pp.135-144.

Harris, M. and Raviv, A. (2005). Allocation of decision-making authority. Review of Finance, 9(3), pp.353-383.

Hart, O. (1995). Firms, contracts, and financial structure. Oxford: Clarendon Press.

Hart, O. and Moore, J. (1990). Property rights and the nature of the firm. The Journal of Political Economy, 98(6), pp.1119-1158. 
Heide, J.B. and John, G. (1992). Do norms matter in marketing relationships? Journal of Marketing, 56(2), pp.32-44.

Hendrikse, G. and Windsperger, J. (2011). Determinants of contractual completeness in franchising. In M. Tuunanen, J. Windsperger, G. Cliquet, \& G. Hendrikse (Eds.), New developments in the theory of networks: franchising, alliances and cooperatives (pp. 13-30). New York: Springer.

Hippmann, P. and Windsperger, J. (2012). Formal and real authority in interorganizational networks: the case of joint ventures. Managerial and Decision Economics, DOI: 10.1002/mde.2592.

Jensen, M.C. and Meckling, W.H. (1992). Specific and general knowledge and organizational structure. In L. Werin, \& H. Wijkander (Eds.), Contract economics (pp. 251-274). Oxford:Blackwell.

Jose, P.E. (2008). ModGraph-I: a programme to compute cell means for the graphical display of moderational analyses: the internet version (Version 2.0). Victoria University of Wellington, New Zealand: Wellington.

Joshi, A.W. and Campbell, A.J. (2003). Effects of environmental dynamism on relational governance in manufacturer-supplier relationships: a contingency framework and an empirical test. Journal of the Academy of Marketing Science, 31(2), pp.176-188.

Joshi, A.W. and Stump, R.L. (1999). The contingent effect of specific asset investments on joint action in manufacturer-supplier relationships: an empirical test of the moderating role of reciprocal asset investments, uncertainty, and trust. Journal of the Academy of Marketing Science, 27(3), pp.291-305.

Joskow, P.L. (2005). Vertical integration. In C. Ménard, \& M.M. Shirley (Eds.), Handbook of new institutional economics (pp. 319-348), Netherlands: Springer.

Karimi, J., Somers, T.M. and Gupta, Y.P. (2004). Impact of environmental uncertainty and task characteristics on user satisfation with data. Information Systems Research, 15(2), pp.175-193.

Kim, J. and Mahoney, J.T. (2005). Property rights theory, transaction costs theory, and agency theory: an organizational economics approach to strategic management. Managerial and Decision Economics, 26, pp.223-242.

Klein, B., Crawford, R.G. and Alchian, A.A. (1978). Vertical integration, appropriable rents, and the competitive contracting process. Journal of Law and Economics, 21(2), pp.297-326.

Koss, P.A. and Eaton, B.C. (1997). Co-specific investments, hold-up and self-enforcing contracts. Journal of Economic Behavior \& Organization, 32, pp.457-470.

Lawrence, P.R. and Lorsch, J.W. (1967). Differentiation and integration in complex organizations. Administrative Science Quarterly, 12(1), pp.1-47.

March, J.G. and Simon, H.A. (1958). Organizations. New York: Wiley.

Martinez-Noya, A., Garcia-Canal, E. and Guillen, M.F. (2012). R\&D outsourcing and the effectiveness of intangible investments: Is proprietary core knowledge walking out of the door? Journal of Management Studies, 50(1), pp.67-91.

Masten, S.E. (1984). The organization of production: evidence from the aerospace industry. Journal of Law and Economics, 27, pp.403-417.

Meyr, H., Wagner, M. and Rohde, J. (2005). Structure of advanced planning systems. In H. Stadler, \& C. Kilger (Eds.). Supply chain management and advanced planning: concepts, models, software and case studies (pp. 109-116), Heidelberg: Springer.

Mikkola, J.H. (2003). Modularity, component outsourcing, and inter-firm learning. R\&D Management. 33(4), pp.439-454.

Milgrom, P. and Roberts, J. (1992). Economics, organization \& management. New York: Prentice Hall. 
Milgrom, P. and Roberts, J. (1995). Complementarities and fit strategy, structure, and organizational change in manufacturing. Journal of Accounting and Economics, 19(2-3), pp.179-208.

Mumdžiev, N. and Windsperger, J. (2011). The Structure of decision rights in franchising networks: a property rights perspective. Entrepreneurship Theory and Practice, 35(3), pp.449-465.

Mumdžiev, N. and Windsperger, J. (2013). An extended transaction cost model of decision rights allocation in franchising: the moderating role of trust. Managerial and Decision Economics, DOI: 10.1002/mde. 2581 .

Rokkan, A.I., Heide, J.B. and Wathne, K.H. (2003). Specific investments in marketing relationships: expropriation and bonding effects. Journal of Marketing Research, 40(2), pp.210-224.

Segal, I.R. and Whinston, M.D. (2000). Exclusive contracts and protection of investments. The Rand Journal of Economics, 31(4), pp.603-633.

Simon, H.A. (1957). Models of man. New York: John Wiley \& Sons.

Talbot, S., Lefebvre E. and Lefebvre L.A. (2007). Closed-loop supply chain activities and derived benefits in manufacturing SMEs. Journal of Manufacturing Technology Management, 18(6), pp.627658.

Thompson, J.D. (1967). Organizations in action. New York: McGraw-Hill.

Vázquez, X.H. (2004). Allocating decision rights on the shop floor: a perspective from transaction cost economics and organization theory. Organization Science, 15(4), pp.463-480.

Wang, E.T.G. and Wei, H.L. (2007). Interorganizational governance value creation: coordinating for information visibility and flexibility in supply chains. Decision Sciences, 38(4), pp.647-674.

Wesrgren, R.E. (2000). The 3Rs of strategic alliance formation: resources, rents, and (property) rights. Annual Research Conference of the Food and Agricultural Marketing Policy, January 13-14, Orlando, Florida.

Williamson, O.E. (1975). Markets and hierarchies: analysis and antitrust implications. New York: Free Press.

Williamson, O.E. (1985). The economic institutions of capitalism. New York: The Free Press.

Windsperger, J. (2004). Centralization of franchising networks: evidence from the Austrian franchise sector. Journal of Business Research, 57(12), pp.1361-1369.

Windsperger, J. and Jell, M. (2005). Structuring residual income and decision rights under internal governance: results from the Hungarian trucking industry. Managerial and Decision Economics, 26, pp.295-305.

Winston, M.D. (2003). On the transaction cost determinants of vertical integration. Journal of Law, Economics, and Organization, 19(1), pp.1-23.

Xue, L., Ray, G. and Gu, B. (2011). Environmental uncertainty and IT infrastructure governance: a curvilinear relationship. Information Systems Research, 22(2), pp.389-399.

Young, S. and Tavares, A.T. (2004). Centralization and authority: back to the future. International Business Review, 13, pp.215-237.

Zabojnik, J. (2002). Centralized and decentralized decision making in organizations. Journal of Labor Economics, 20(1), pp.1-22.

http://www.automotivenews.com. The ranking list of top 100 global suppliers, accessed in May 2010. 